\title{
Analysing the Impact of Carbon Emissions and Non-renewable Energy Use on Infant and Under-5 Mortality Rates in Europe: New Evidence Using Panel Quantile Regression
}

\author{
Bosede Ngozi ADELEYE \\ Covenant University \\ Aviral Kumar Tiwari ( $\nabla$ aviral.eco@gmail.com ) \\ Rajagiri Business School https://orcid.org/0000-0002-1822-9263 \\ Muhammed Ibrahim SHAH \\ BRAC University \\ Saif Ullah \\ SZABIST: Shaheed Zulfikar Ali Bhutto Institute of Science and Technology
}

\section{Research Article}

Keywords: carbon emissions, mortality rate, non-renewable energy, socio-economic factors, Europe

Posted Date: December 9th, 2021

DOI: https://doi.org/10.21203/rs.3.rs-1034508/v1

License: () (1) This work is licensed under a Creative Commons Attribution 4.0 International License. Read Full License 


\section{Abstract}

The concentration of greenhouse gas emissions is considered to increase, and this can undermine the access to basic resources that are necessary for leading a healthy life such as access to food, water, health and environment. Environmental health is closely linked to human health and the world is witnessing an exponential increase in the trend of the greenhouse gas emissions which pose significant threat to both the environment and human health. Hence, this study contributes to the health-environment discourse and uses an unbalanced panel data on 46 European countries from 2005 to 2015 to investigate the impact of carbon emissions and non-renewable energy on infant and under-5 mortality rates. Consistent findings from static and dynamic analyses reveal that: (1) carbon emissions exhibit mortality-inducing properties; (2) non-renewable energy show mortality-reducing properties; (3) persistency in mortality rates exist; (4) the exacerbating (reducing) impact of emissions (non-renewable energy) dwindles (increases in absolute values) at higher distributions of mortality rates; and (5) Euro Union countries show lower mortality rates relative to non-Euro Union members. Policy recommendations are discussed.

JEL Classification: I00, I10, I15, I18, I19

\section{Introduction}

Environmental health is closely linked to human health and the world is witnessing an exponential increase in the trend of greenhouse gas emissions (GHG) which pose significant threat to the environment and human health (Mujtaba and Shahzad, 2020). Several studies have shown that increase in output growth can help an economy raise its health funds as well as expenditures for the protection of the environment. To be more specific, rapid economic growth has resulted in exponential increase in emissions throughout the world and the occurrence of diseases have also amplified (Badulescu et al.,2019). Thus, rapid economic growth is undermining the health status of individuals in both developed and developing countries (Alimi et al.,2019). There are several factors that determine human health such as safe drinking water, clean air, sufficient food and secure shelter and climate change (Geels et al, 2015; Orru et al. 2019; Kushta et al, 2021). The World Health Organisation (WHO) therefore emphasizes on access to safe water and sanitation services, clean air and housing conditions (Badulescu et al., 2019) as a pre-cursor to ensuring good health and longevity.

The World Health Organization (2018) projected that in 2030-2050 about 250,000 deaths annually can be attributed to climate change. This seems to be a probability given the pattern of the GHG emissions during the last decades. Although countries have been implementing climate mitigation policies in their respective territories, the world has witnessed a rise in GHG emissions by $2.2 \%$ per year between 2000 to 2010 compared to only $1.3 \%$ during 1970 -

2000 (Edenhofer,2015). Among the greenhouse gas emissions, carbon emission which is linked to intense consumption of nonrenewable energy resources is one of the major drivers behind global warming and environmental degradation with negative impact on human health (Nathaniel and Adeleye, 2021). During 1970-2010, approximately $78 \%$ of total greenhouse gas emissions were attributed to carbon emissions from fossil fuel combustion and industrial processes (Edenhofer, 2015). Furthermore, the concentration of GHG emissions is projected to increase the world temperature by $2^{\circ} \mathrm{C}$ and $3^{\circ} \mathrm{C}$ in the upcoming 50 years which can undermine access to basic resources that are necessary for leading a healthy life such as access to food, water, health and environment. Also, the direct effect of climate change can be seen from the rising sea level as well as the increase in heat waves (GEA,2012). The indirect effect of climate change on health can be realized in the form of changes in nutrition and development of infectious diseases (Pablo-Romero et al.,2016; Orru et al., 2013).

Energy, on the other hand, is necessary for economic growth, productivity as well as human development. The need to replace fossil fuels with renewable resources is more urgent than ever which will not only help economies achieve sustainability in terms of environment but also in terms of economic perspective since a healthy population is crucial to economic productivity and sustainable development (WHO,2002). It is clear that as the world population continues to increase, the quest for energy increases. However, if these energy requirements are met by continuously burning fossil fuel, it will in turn affect the world population who will suffer injuries and deaths due to fossil fuel combustion. Furthermore, the empirical literature documents that nonrenewable energy (NRE) consumption is associated with adverse human capital impact (Anser et al. 2020; Shobande, 2020; Asghar et al. 2020; Sarkodie et al., 2019) which ought to be further investigated and serves as the motivation for this study.

The focus on Europe is germane. The United States Environmental Protection Agency (2017) reports that European Union countries are one of the top carbon emitters after USA and China and the effect of climate change has mostly been felt in the region through the heat waves. Although, European countries have invested considerably to increase the quality of their environment by building renewable and clean energy technologies, the impacts of emissions and pollution on human health in these countries is still significant which is posing burden on their health budgets as well (Geels et al., 2015; Orru et al, 2013, 2015; Kushta et al., 2021). Global warming is considered to be the new health threat for Europe (McKee and Jacobson, 2000) and some studies document the environmental impact of environmental pollution and climate change on health, adolescent and premature mortalities in Europe. Aside contributing negatively towards human health, the hot temperatures resulting from global warming has widespread effects in the region (Caruso et al., 2020; Sarofin et al., 2017; Barreira et al 2017; Meehl and Tebaldi, 2004; Robine et al., 2008). From an integrated assessment model, Geels et al. (2015) showed that a positive relationship between changes in climate, air pollution and premature deaths such that reductions in emissions cause a large significant decrease in mortality. Using comparative analysis, Orru et al (2013) showed that increase in climate change causes increase in the concentration of ground-level ozone which is associated with respiratory morbidity and mortality. This is similar to the findings of Anderson et al (2004) who conclude that acute health effects such as respiratory and cardiovascular disease are the resultant outcomes of increasing ground-level ozone (Bell et al., 2005; Gryparis et al., 2004; Ito et al., 2005; Levy et al., 2005), and chest tightness and asthma (Mortimer et al., 2002; Amann et al., 2005). Similarly, increase in ambient ozone levels is associated with increase in hospital admissions for respiratory diseases and chronic obstructive pulmonary diseases (Burnett et al., 1997; Anderson et al., 1997; Peters et al., 1999)

The noticeable lacuna in these studies is the non-consideration of the impact carbon emissions and non-renewable energy in addition to other socio-economic factors that may affect infant and under-5 mortalities in Europe. This is the gap our paper sets to fill. Therefore, we extend these studies by engaging a 
comprehensive examination of infant and under-5 mortalities in Europe. In addition, we probe the discourse on the effects of atmospheric pollution using carbon dioxide emissions (Ari et al., 2018; Shahbaz et al., 2019; Churchill et al., 2018; Nkengfack et al., 2020) which is a component of greenhouse gas (GHG) and non-renewable energy consumption. Given these, we contribute to the health-environment literature by investigating the intrinsic nexus of carbon emissions, energy usage and a set of socio-economic variables on infant and under-5 mortality rates in Europe. The objectives of the study are threefold: (1) show whether carbon emissions and nonrenewable energy independently impact infant and under-5 mortality rates; (2) if the impact is significantly different across the dis-aggregated groups; and (3) if mortality rate is persistent. To achieve these objectives, we use an exclusive data on 46 European countries disaggregated into Euro Union and non-Euro Union countries from 2005 to 2015 . We deployed a blend of three static and dynamic estimation techniques - panel spatial correlation consistent least squares dummy variable (PSCC-LSDV), system generalised method of moments (GMM), and quantile regressions - to ascertain the robustness of our results and to explore if there are significant differences between the two groups. To the best of knowledge, this is the first study to adopt this approach. Our results hold when we control for time varying common shocks and regional fixed effects. For the most part our results are consistent. We find that carbon emissions display mortality-increasing properties, non-renewable energy reduces mortality rates, persistency in mortality rates exist and Euro Union countries show lower mortality rates than non-Euro Union members. The rest of the study is structured as follows: Section 2 discusses the empirical literature; Section 3 outlines the data and model; Section 4 interprets the results and Section 5 concludes with policy recommendations.

\section{Literature Review}

The impact of carbon emissions and environmental degradation on health indicators have been examined extensively in the empirical literatures (Mehrara \& Nasibparast, 2013; Ali \& Audi, 2016; Kolasa-Więcek \& Suszanowicz, 2019; Hossain et al., 2020; Shobande, 2020). These studies can be grouped into three strands of the literature. The first deals with the relationship between the life expectancy and environment, the second documents the association between mortality and environment and the third strand argues on the relationship between the environment and health expenditures. From the first strand, it has been conclusively argued that environmental degradation can lead to lower life expectancy. For instance, Ali and Audi (2016) deployed the ARDL technique and found that environmental degradation and life expectancy have significant negative relationship in Pakistan. Using similar approach, Hossain et al. (2020) showed that life expectancy and environmental degradation exert negative relationship in Bangladesh. Employing neural network approach, Kolasa-Więcek and Suszanowicz (2019) investigated the correlation between life expectancy and air pollution in Europe. The most frequent correlation in their analysis was observed for fine particles, indicating that fine particles have greater influence compared to other pollutants on European residents.

As has been already mentioned, second strand of literature deals with the relationship between the environment and mortality. Mehrara and Nasibparast (2013) examined the factors determining child mortality for developing countries using Bayesian Model Averaging approach. The results revealed that per capita GDP as well as literacy rate negatively affect child mortality rate. Erdoğan et al. (2019) used infant mortality and life expectancy as health indicators to analyse how they are affected by carbon emissions in Turkey. The study found that a rise in carbon emissions increases infant mortality rate and simultaneously decreases life expectancy. Similarly, Owusu and Sarkodie (2020) examined the association among ambient particulate matter and ozone, mortality and welfare cost for 195 countries and found strong evidence for the impact of air pollution on premature deaths, mortality and daily adjusted life years. Most of the aforementioned studies use carbon emissions as a proxy for environmental degradation. However, Jian et al. (2017) constructed an environmental quality index and assessed its effects on mortality rate for USA. This index was created out of 5 variables such as land, water, built, air and socio demographics. Findings revealed that if environmental quality is poor, mortalities increase. In another study, Patel (2018) found that infant mortality increased monotonically due to poor air quality among non-Hispanics whites and blacks. Detailed examination of the dynamic interdependence among health, carbon emissions and economic growth was carried out by Katrakilidis et al. (2016) for Greece. Employing the Kuznets-type models, their causality result identified causal effects from income to infant mortality and carbon emissions.

The third strand of literature deals with the environmental quality and health expenditures. Ahmad et al. (2018), considered carbon emissions from coal, natural gas and petrol as measures of environmental degradation and explored how the increase in these emissions can affect health quality of China. They found long-run negative impact of these emissions on health status. Yu et al. (2016), on the other hand, analysed Chine's provinces to see if there is any relationship between health care spending and environmental indicators. They found that public health expenditure is positively related to economic growth and environmental quality. In a different framework, Farooq et al. (2019) found that carbon emissions increase health issues for 30 Chinese provinces. The study also found that population is an effective determinant of health issues. Recently, Zeeshan et al. (2021) attempted to analyse the asymmetric relationship among carbon emissions, pollution, and household health expenditures in China. Using nonlinear autoregressive distributed lag (NARDL), they found positive impacts on health spending due to positive shocks of carbon emissions and environmental pollution in long- and short-runs but they found that health spending is negatively affected by the negative shocks. On 15 ECOWAS countries, Alimi et al. (2019) analysed how national healthcare expenditure, private and public health care expenditure can be affected via environmental quality. Employing panel data techniques, the study found that environmental pollution, proxied by carbon emissions, positively affect the overall health expenditure and public healthcare expenditure. Taking this into account, Badulescu et al. (2019) used European countries to demonstrate how environmental pollution along with non-communicable diseases and economic growth can determine health expenditures. Economic growth was found to be a critical determinant for health expenditures in both the short- and long run. However, the result was mixed for the effect of carbon emissions on health expenditures.

A cross country analysis of 51 countries based on income groups was carried out by Chaabouni et al. (2016) who examined the causal relationship between carbon emissions, health expenditures and economic growth. The result showed that health expenditures and economic growth, carbon and economic growth are bi-directionally related. Shahzad et al. (2020) showed that renewable energy consumption negatively and significantly affected the health expenditures in Pakistan similar to the findings of Ullah et al. (2020). Empirical studies have also been carried out using OECD countries to determine relationship between health status and other indicators including environmental quality. Mujtaba and Shahzad (2020) analysed the relationship among economic growth, environmental pollution and public health for OECD countries. Their result revealed that carbon emission and renewable energy Granger-cause healthcare spending in OECD economies. Lastly, Wang et al. (2019) also investigated the OECD countries to examine long run association among GDP, carbon and health

Page $3 / 15$ 
care expenditure. The results revealed that healthcare and GDP are bi-directionally related for Germany and USA. Results of New Zealand and Norway showed two-way relationship between healthcare spending and $\mathrm{CO}_{2}$ emissions while for Canada, Germany and USA, bidirectional causality was found between GDP growth and carbon emissions. What is missing in the literature is a comprehensive, cross-country analysis of impact of carbon emissions, non-renewable energy and other socio-economic factors that influence infant and under-5 mortality rate in Europe. We differ by engaging more robust analyses using aggregated and dis-aggregated sample, static and dynamic estimation techniques to interrogate these inter-woven relationships.

\section{Data And Empirical Approach}

\subsection{Data}

This study fills a gap in the literature by interrogating the health-environment dynamics in Europe. To achieve the stated objectives, an unbalanced panel data of 46 European countries is used from 2005 to 2015. The study uses a total of ten variables. Two dependent variables - infant (MINF) and under-5 (MU5) mortality rates; two key explanatory variables - carbon emissions (CO2PC) and nonrenewable energy $(E N U P C)$ and six control variables - per capita GDP $(P C)$; female secondary school enrolment (SECF), health expenditure per capita (HEXPC), urbanization (URB), access to basic sanitation (BSAM) and inflation rate (INFL). All variables are sourced from World Bank (2020) World Development Indicators. On a priori expectations, carbon emissions, nonrenewable energy, inflation, and urban population are expected to increase mortality rates. Hence, positive coefficients are expected. Whereas, per capita income, female secondary school enrolment, health expenditures, basic sanitation, are expected to reduce mortality rates. Table 1 details the variables description, sources and expected signs.

\begin{tabular}{lll} 
Table 1 & \multicolumn{1}{c}{ Variables Description and Expectations } & Expectations \\
\hline Code & Variables & N/A \\
\hline MINF & Mortality rate, infant (per 1,000 live births) & N/A \\
\hline MU5 & Mortality rate, under-5 (per 1,000 live births) & + \\
\hline CO2PC & CO2 emissions (metric tons per capita) & - \\
\hline ENUPC & Non-renewable energy consumption per capita & - \\
\hline PC & GDP per capita (constant 2010 US\$) & - \\
\hline HEXPC & Current health expenditure per capita (current US\$) & - \\
\hline SECF & School enrolment, secondary, female (\% gross) & + \\
\hline INFL & Inflation, consumer prices (annual \%) & - \\
BSAN & People using at least basic sanitation services (\% of population) \\
\hline URB & Urban population (\% of total population) \\
\hline
\end{tabular}

Note: MINF = infant mortality rates; MU5 = under-5 mortality rate; $C O 2 P C=$ carbon emissions per capita; $E N U P C=$ non-renewable energy per capita; $\mathrm{PC}=$ GDP per capita (constant 2010); HEXPC = health expenditure per capita; $S E C F=$ female secondary school enrolment; INFL = inflation rate; $B S A N=$ access to basic sanitation; URB = urban population; N/A = not applicable.

Source: Authors' Compilations.

\subsection{Models and Specifications}

To address the first and second objectives, mortality rate (infant and under-5) model is expressed as a function of carbon emissions, non-renewable energy, and a set of control variables. Adapting, Adeleye, Adedoyin, and Nathaniel (2020) and Adeleye, Gershon, Ogundipe, Owolabi, Ogunrinola, and Adediran (2020), the equation is stated as:

$$
\ln M_{i t}=\eta_{0}+\eta_{1} \ln C O 2 P C_{i t}+\eta_{2} \ln E N U P C_{i t}+\psi^{\prime} Z_{i t}+d_{t}+e_{i t}
$$

Where $\mathrm{M}$ represents infant mortality/under-5 mortality rate; In denotes natural logarithm; $Z$ is a vector of control variables (PC, HEXPC, SECF, INFL, BSAN, URB); $\eta \mathrm{i}, \psi$ are parameters to be estimated; is time dummy that controls for yearly variations of the dependent variable; is the error term. To control for outliers and establish an elasticity relationship, all variables except for INFL are transformed into their natural logarithms to capture elasticities, account for skewness and nonlinear relationship between the outcome and explanatory variables. The variables are as defined in Table 1.

To address the third of objective of investigating the persistency of mortality rates, equation [1] is augmented to include the lagged values of mortality rates and the equation is expressed as:

$$
\ln M_{i t}=\gamma_{0}+\gamma_{1} \ln M_{i t-1}+\gamma_{2} \ln C O 2 P C_{i t}+\gamma_{3} \ln E N U P C_{i t}+\xi^{\prime} Z_{i t}+d_{t}+v_{i t}
$$

Where yi, $\xi$ are parameters to be estimated; $d$ is time dummy that controls for yearly variations of the dependent variable; $v$ is the error term. Lastly, to check if the outcomes of Equation [1] differ by union classification, the sample is divided into two distinct groups[1]: (i) Euro Union members[2] and (ii) non-Euro Union members. 
This study follows Shobande (2020) and employs both static and dynamic models to investigate the health-environment dynamics. These techniques have been used various panel data studies (Adeleye \& Eboagu, 2019; Adusei, Adeleye, \& Okafor, 2020; Niebel, 2014). For the static model, panel spatial correlation consistent least squares dummy variables techniques (PSCC-LSDV) along with the two-step system GMM is used to analyse the dynamic model. The PSCC estimator uses the Driscoll and Kraay (1998) robust standard errors technique and corrects the standard errors of the coefficient estimates for possible dependence (Cameron \& Trivedi, 2005; Hoechle, 2006). The underlying algorithm routines the OLS/WLS[1] and fixed effects (within) regression and computes spatial correlation consistent standard errors for linear panel models. The LSDV technique, also known as the fixed effects, have the advantage of accounting for heterogeneities across the panel observations using dummy variables.

In the event that the dependent and independent variables may be not strictly exogenous, the two-step system generalized methods of moments (Sys-GMM) is used to analyse the dynamic model. Sys-GMM also controls for endogeneity, heteroscedasticity and omitted variables (Arellano \& Bond, 1991; Blundell \& Bond, 1998; Roodman, 2014). Endogeneity broadly refers to situations in which an explanatory variable is correlated with the error term. Li (2016) noted that endogeneity problem creates problem for true relationships among variables. Instrument variables are also used to control problems like endogeneity as suggested by Anderson and Hsiao (1982). Many recent studies like Noman, Gee and Isa (2020) and Bashir, Khan, Jones \& Hussain (2020) studies financial stability variable as endogenous. Kim (2017) also used GMM model to control endogeneity problem in banking sector. Huq, Ashraf, Gupta, and Zheng (2018) used two-step GMM by modelling the financial stability of banks. Arellano and Bond (1991) first induced the GMM that used instruments variables and Hansen (1982) used lagged variable of dependent variables in GMM to obtain robust estimations. Finally, in the event that the dependent variables exhibit non-normal distributions such that the impact of the covariates change along their conditional distribution, it becomes relevant to deploy a suitable technique that models this scenario. The most appropriate is the quantile regressions proposed by Koenker and Basset (1978); Koenker and Hallock (2001); Koenker (2005). This technique is also more robust in the presence of outliers or weaker linear correlation between variables (Brida et al., 2020).

\section{Results And Discussion}

\subsection{Summary Statistics}

Presented in Table 2 is the detailed summary of the model variables which includes the full sample statistics, as well as the statistics for countries in the European Union (EU) and those outside the union. The mean values of infant mortality rate and under-5 mortality rate of children per 1000 live births within the full sample consideration are 6.52 and 7.645 respectively. This shows that for every recorded $1000^{\text {th }}$ births, there are about 7 infants and approximately 8 under- 5 children's mortalities. The European countries' healthcare focus on child life according to the sample statistic above reveal that only about 4 infants and 5.127 children below age 5 die at birth, when compared to 1000 children born within the same sample period. For the non-EU nations, about twice the number of infant (9.795) and under-5 (11.283) deaths per 1000 live births are observed. Also, the average values of carbon emissions, non-renewable energy per individual, income, health expenditure by government, enrolment and inflation rates, sanitation, urban population as well as natural resources rent are reported as seen on Table 2 for the full sample, EU and non-EU zones respectively.

\subsection{Pairwise Correlation Analysis}

Table 3 displays the pairwise correlations evidenced in the data and the associations are statistically significant at the $1 \%, 5 \%$ and $10 \%$ levels, respectively. All the variables with the exception of inflation rate (INFL) show statistically significant with infant mortality and under-5 mortality rates. Due to the high collinearity coefficient of 0.946 between $P C$ and $H E X P C$ both variables are excluded in subsequent analyses to test the robustness of our results.

Table 2 Summary Statistics

\begin{tabular}{|c|c|c|c|c|c|c|c|c|c|c|c|c|}
\hline \multirow[t]{2}{*}{ Variable } & \multicolumn{4}{|c|}{ Full Sample } & \multicolumn{4}{|c|}{ European Union } & \multicolumn{4}{|c|}{ Non-European Union } \\
\hline & Mean & Std. Dev. & Min & Max & Mean & Std. Dev. & Min & Max & Mean & Std. Dev. & Min & $\mathrm{N}$ \\
\hline MINF & 6.52 & 5.813 & 1.7 & 44.6 & 4.252 & 2.039 & 1.8 & 15.2 & 9.795 & 7.654 & 1.7 & 44 \\
\hline MU5 & 7.645 & 6.64 & 2.2 & 52.5 & 5.127 & 2.404 & 2.2 & 18 & 11.283 & 8.788 & 2.2 & 52 \\
\hline $\mathrm{CO} 2 \mathrm{PC}$ & 6.772 & 3.516 & 1.299 & 24.825 & 7.746 & 3.614 & 3.353 & 24.825 & 5.491 & 2.933 & 1.299 & 12 \\
\hline ENUPC & 3373.846 & 2569.326 & 679.862 & 18178.14 & 3557.21 & 1483.373 & 1591.668 & 9428.811 & 3096.321 & 3630.706 & 679.862 & $1 \varepsilon$ \\
\hline PC & 27262.08 & 24094.51 & 2061.547 & 111968.4 & 32478.54 & 21528.33 & 5607.713 & 111968.4 & 20480.69 & 25569.95 & 2061.547 & 91 \\
\hline HEXPC & 2475.279 & 2310.227 & 79.332 & 10014.71 & 2776.047 & 1958.296 & 254.53 & 7639.851 & 1986.529 & 2725.078 & 79.332 & $1 c$ \\
\hline SECF & 103.576 & 16.136 & 76.098 & 174.678 & 107.439 & 17.031 & 83.272 & 174.678 & 96.22 & 11.06 & 76.098 & 12 \\
\hline INFL & 3.839 & 5.518 & -4.478 & 59.22 & 2.312 & 2.319 & -4.478 & 15.402 & 6.067 & 7.671 & -2.41 & $5 c$ \\
\hline BSAN & 95.26 & 5.935 & 71.619 & 100 & 96.382 & 5.133 & 75.091 & 99.995 & 93.723 & 6.594 & 71.619 & $1 c$ \\
\hline URB & 69.493 & 13.196 & 42.49 & 97.876 & 71.128 & 12.066 & 51.533 & 97.876 & 67.256 & 14.332 & 42.49 & $9:$ \\
\hline
\end{tabular}

Note: MINF = infant mortality rates; MU5 = under-5 mortality rate; CO2PC = carbon emissions per capita; ENUPC = nonrenewable energy per capita; PC = GDP capita (constant 2010); HEXPC = health expenditure per capita; SECF = female secondary school enrolment; INFL = inflation rate; $B S A N=$ access to basic san URB = urban population.

Source: Authors' Computations 
Table 3 Correlation Analysis

\begin{tabular}{|c|c|c|c|c|c|c|c|c|c|c|}
\hline Variables & 1 & 2 & 3 & 4 & 5 & 6 & 7 & 8 & 9 & 10 \\
\hline (1) InMINF & 1.000 & & & & & & & & & \\
\hline (2) InMU5 & $0.998 * \star \star$ & 1.000 & & & & & & & & \\
\hline (3) InCO2PC & $-0.625^{\star \star \star}$ & $-0.615^{\star \star \star}$ & 1.000 & & & & & & & \\
\hline (4) InENUPC & $-0.741^{\star \star \star}$ & $-0.729 * \star \star$ & $0.788 * \star \star$ & 1.000 & & & & & & \\
\hline (5) $\ln P C$ & $-0.801 * \star \star *$ & $-0.803^{\star \star \star}$ & $0.664^{\star * *}$ & $0.768^{\star \star \star}$ & 1.000 & & & & & \\
\hline (6) InHEXPC & $-0.815^{\star \star \star}$ & 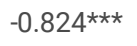 & $0.568^{\star * *}$ & $0.709 * \star \star$ & $0.976 * \star \star$ & 1.000 & & & & \\
\hline (7) InSECF & $-0.573^{\star \star \star}$ & $-0.570 \star \star \star *$ & $0.337 * \star \star$ & $0.468 * \star \star$ & $0.543^{\star * *}$ & $0.550 * \star \star$ & 1.000 & & & \\
\hline (8) INFL & $0.312^{\star \star \star}$ & 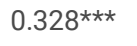 & $-0.089 *$ & $-0.099 \star \star$ & 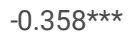 & $-0.438 * \star \star$ & $-0.199 \star \star \star *$ & 1.000 & & \\
\hline (9) InBSAN & $-0.725^{\star \star \star}$ & $-0.735^{\star \star \star}$ & $0.459 * \star \star$ & 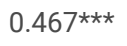 & $0.603^{\star \star \star}$ & $0.648 * \star \star$ & $0.382^{\star \star \star}$ & $-0.260 * \star \star$ & 1.000 & \\
\hline (10) InURB & 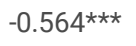 & $-0.561 * \star \star$ & $0.555^{\star \star \star}$ & $0.708 * \star \star$ & $0.691^{\star \star \star *}$ & $0.641^{\star * *}$ & $0.593^{\star \star *}$ & $-0.081 *$ & $0.518 * \star \star$ & 1.000 \\
\hline
\end{tabular}

Note: $* \star *, * \star$, and $*$ denote statistical significance at the $1 \%, 5 \%$, and $10 \%$ levels, respectively; In = natural logarithm; MINF $=$ infant mortality rates; MU5 $=$ under-5 mortality rate; $\mathrm{CO} 2 \mathrm{PC}=$ carbon emissions per capita; ENUPC = nonrenewable energy per capita; $\mathrm{PC}=$ GDP per capita (constant 2010 ); HEXPC = health expenditure per capita; $\mathrm{SECF}=$ female secondary school enrolment; INFL = inflation rate; BSAN = access to basic sanitation; URB = urban population; TNRR = total natural resource rent.

Source: Authors' Computations

\subsection{Results from Static Models}

\subsubsection{PSCC-LSDV Results, Full Sample}

Controlling for yearly variation of the dependent variable, results from PSCC-LSDV technique are presented in Table 4. Columns [1] and [2] show that infant and under- 5 mortality rate is exaggerated by the incident of carbon emissions across the model specifications. These outcomes support Mutizwa and Makochekanwa (2015), Fotourehchi (2016), Ahmad et al. (2016), Adedotun et al. (2018), and Erdogan et al. (2019). However, contrary to Anser et al., (2020) and Asghar et al., (2020), non-renewable energy consumption exhibit mortality-reducing properties. This can be explained by the fact that European economies' higher share of energy still come from fossil fuel sources whose extraction of materials from these non-renewable resources are then utilized to improve the health outcomes. Also, the control variables with the exception of urbanization, have significant reducing impact on mortality rates. 
Table 4 PSCC-LSDV Results, Full Sample

\begin{tabular}{|c|c|c|c|c|}
\hline \multirow[t]{3}{*}{ Variables } & \multicolumn{2}{|l|}{ Main Model } & \multicolumn{2}{|c|}{ Robustness Model } \\
\hline & [1] & [2] & [3] & [4] \\
\hline & InMINF & InMU5 & InMINF & InMU5 \\
\hline \multirow[t]{2}{*}{ InCO2PC } & $0.0537 \star \star \star *$ & $0.0395^{\star \star}$ & $0.0454^{\star \star}$ & $0.0369 *$ \\
\hline & $(3.57)$ & $(2.55)$ & $(2.25)$ & $(1.86)$ \\
\hline \multirow[t]{2}{*}{ InENUPC } & 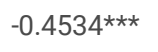 & $-0.4092^{\star \star \star}$ & $-0.5982^{\star \star \star}$ & $-0.5572^{\star \star \star}$ \\
\hline & $(-35.23)$ & $(-37.45)$ & $(-39.12)$ & $(-37.72)$ \\
\hline \multirow[t]{2}{*}{$\ln \mathrm{PC}$} & $-0.1200 * \star$ & $-0.0876^{\star}$ & & \\
\hline & $(-2.33)$ & $(-1.85)$ & & \\
\hline \multirow[t]{2}{*}{ InHEXPC } & $-0.0890 *$ & $-0.1202^{\star *}$ & & \\
\hline & $(-1.70)$ & $(-2.52)$ & & \\
\hline \multirow[t]{2}{*}{ InSECF } & $-0.3538^{\star \star \star}$ & $-0.3089 \star \star \star *$ & 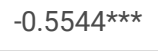 & $-0.5343^{\star \star \star}$ \\
\hline & $(-6.00)$ & $(-5.33)$ & $(-23.61)$ & $(-21.95)$ \\
\hline \multirow[t]{2}{*}{ INFL } & $-0.0073^{\star \star}$ & $-0.0055^{\star}$ & 0.0054 & 0.0077 \\
\hline & $(-2.22)$ & $(-1.81)$ & $(0.82)$ & $(1.18)$ \\
\hline \multirow[t]{2}{*}{ InBSAN } & $-2.7914^{\star \star \star}$ & $-2.7070 \star \star \star$ & $-3.5549 * \star \star$ & $-3.5137 \star \star \star$ \\
\hline & $(-20.66)$ & $(-21.19)$ & $(-16.12)$ & $(-15.96)$ \\
\hline \multirow[t]{2}{*}{ InURB } & $0.6940^{\star \star \star *}$ & $0.6716^{\star \star \star}$ & $0.5387^{\star \star \star}$ & $0.5268^{\star \star \star}$ \\
\hline & $(29.07)$ & $(36.12)$ & $(17.71)$ & $(18.69)$ \\
\hline \multirow[t]{2}{*}{ Euro Union } & $-0.2474 \star \star \star$ & $-0.2243^{\star \star \star}$ & $-0.2673^{\star \star \star}$ & $-0.2382^{\star \star \star}$ \\
\hline & $(-10.18)$ & $(-10.29)$ & $(-7.53)$ & $(-7.03)$ \\
\hline \multirow[t]{2}{*}{ Constant } & $18.7124^{\star \star \star}$ & $17.9451^{\star \star \star}$ & 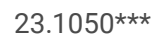 & $22.7125^{\star \star \star}$ \\
\hline & $(21.07)$ & $(20.86)$ & $(22.85)$ & $(22.15)$ \\
\hline VIF & 5.92 & 5.92 & 2.02 & 2.02 \\
\hline Time Dummies & Yes & Yes & Yes & Yes \\
\hline No. of Obs. & 390 & 390 & 407 & 407 \\
\hline R-Squared & 0.872 & 0.878 & 0.843 & 0.841 \\
\hline F Statistic & 41309.923 & 65552.458 & 25200.988 & 20038.360 \\
\hline
\end{tabular}

Note: $* \star *, * *$, and $*$ denote statistical significance at the $1 \%, 5 \%$, and $10 \%$ levels, respectively; In = natural logarithm; MINF $=$ infant mortality rates; MU5 $=$ under-5 mortality rate; $\mathrm{CO} 2 \mathrm{PC}=$ carbon emissions per capita; ENUPC = nonrenewable energy per capita; $\mathrm{PC}=\mathrm{GDP}$ per capita (constant 2010); HEXPC = health expenditure per capita; $\mathrm{SECF}$ = female secondary school enrolment; INFL = inflation rate; BSAN = access to basic sanitation; URB = urban population.

Source: Authors' Computations

For robustness checks, $P C$ and HEXPC are excluded from the analyses due to high collinearity and the bloating of the variance inflation factors (VIF). The results shown in columns [3] and [4] are not significantly different from those of columns [1] and [2] thereby sustaining our earlier findings. We therefore conclude that while carbon emission aggravates infant and under- 5 mortality rates, nonrenewable energy exerts mortality-reducing impact. Furthermore, using non-Euro Union members as the base dummy[1], the intercept coefficients of Euro Union countries are consistently negative which imply that countries in the European Union have lower mortality rates than non-Euro Union members. Lastly, the model's goodness-of-fit show that the R-squared ranges around 0.87 and indication that about $87 \%$ variation in mortality rates is explained by the regressors. Also, the F-statistics shows that all the regressors are jointly significant in explaining mortality rates.

\subsubsection{PSCC-LSDV Results, Sub-Samples}

To further probe the discourse, the sample is divided into two - Euro Union and non-Euro Union samples. A cursory observation of the results shown in columns [5] to [8] reveals some significant differences and interpretation is limited to the variables of interest - carbon emissions, and non-renewable energy. Though negative, the impact of carbon emissions on both sub-samples is statistically not significant for the main models. This outcome may not be unconnected to Europe's stance in promoting environmentally friendly initiatives. While non-renewable energy use shows statistically significant mortality- 
reducing properties across both samples. The switch to cleaner energy may contribute to reducing the impact of non-renewable energy on the incidence of mortality rates in Europe. These are important findings and contributions to the literature.

For robustness checks, $P C$ and HEXPC are excluded from the analyses due to high collinearity and the bloating of the variance inflation factors (VIF). With the exception of carbon emission which indicates a statistically significant negative impact for Euro Union countries, the remaining results shown in columns [9] to [12] are not significantly different from those of columns [5] to [8] thereby sustaining our earlier findings. Contrary to the full sample outcomes, we conclude that both carbon emissions and non-renewable energy exert mortality-reducing impact. These findings are significant additions to the body of knowledge.

Table 5 PSCC-LSDV Results, Sub-Samples

\begin{tabular}{|c|c|c|c|c|c|c|c|c|}
\hline \multirow[t]{4}{*}{ Variables } & \multicolumn{4}{|l|}{ Main Model } & \multicolumn{4}{|c|}{ Robustness Model } \\
\hline & Euro & Euro & Non-Euro & Non-Euro & Euro & Euro & Non-Euro & Non-Euro \\
\hline & [5] & [6] & [7] & [8] & [9] & [10] & [11] & [12] \\
\hline & InMINF & InMU5 & InMINF & InMU5 & InMINF & InMU5 & InMINF & InMU5 \\
\hline \multirow[t]{2}{*}{ InCO2PC } & 0.0063 & -0.0010 & -0.0172 & -0.0248 & $-0.0577 \star \star \star$ & $-0.0590 \star \star \star$ & 0.0171 & 0.0083 \\
\hline & $(0.50)$ & $(-0.08)$ & $(-0.43)$ & $(-0.64)$ & $(-3.98)$ & $(-4.44)$ & $(0.42)$ & $(0.21)$ \\
\hline \multirow[t]{2}{*}{ InENUPC } & 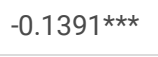 & $-0.1072^{\star *}$ & $-0.5129 \star \star \star$ & $-0.4790 \star \star \star$ & $-0.2713^{\star \star \star}$ & $-0.2503^{\star \star \star}$ & $-0.6575^{\star \star \star}$ & $-0.6203^{\star \star \star}$ \\
\hline & $(-3.45)$ & $(-2.77)$ & $(-22.90)$ & $(-28.16)$ & $(-8.61)$ & $(-8.66)$ & $(-28.10)$ & $(-28.01)$ \\
\hline \multirow[t]{2}{*}{$\ln P C$} & $-0.4396^{\star \star \star}$ & $-0.4139 \star \star \star *$ & 0.0917 & 0.1111 & & & & \\
\hline & $(-7.37)$ & $(-7.06)$ & $(0.92)$ & $(1.29)$ & & & & \\
\hline \multirow[t]{2}{*}{ InHEXPC } & $0.1911^{\star \star \star}$ & 0.1591 ** & 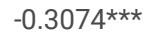 & 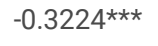 & & & & \\
\hline & $(3.17)$ & $(2.67)$ & $(-3.10)$ & $(-3.82)$ & & & & \\
\hline \multirow[t]{2}{*}{ InSECF } & -0.1129 & -0.0838 & $-1.0762^{\star \star \star}$ & $-0.9577 \star \star \star$ & $-0.1692^{\star}$ & $-0.1593^{*}$ & $-1.6537 \star \star \star$ & $-1.5748^{\star \star \star}$ \\
\hline & $(-0.89)$ & $(-0.64)$ & $(-5.55)$ & $(-6.21)$ & $(-1.98)$ & $(-1.84)$ & $(-10.35)$ & $(-9.72)$ \\
\hline \multirow[t]{2}{*}{ INFL } & $0.0219 \star \star \star$ & $0.0223^{\star \star \star}$ & $-0.0122^{\star \star \star}$ & $-0.0102 \star \star \star$ & $0.0351^{\star \star \star}$ & $0.0371^{\star \star \star}$ & 0.0042 & 0.0064 \\
\hline & $(4.53)$ & $(4.62)$ & $(-3.64)$ & $(-3.38)$ & $(7.12)$ & $(7.04)$ & $(0.68)$ & $(1.05)$ \\
\hline \multirow[t]{2}{*}{ InBSAN } & 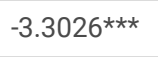 & $-3.1619 \star \star \star *$ & $-2.3545^{\star \star \star}$ & $-2.4200 * \star \star$ & $-3.6875^{\star \star \star}$ & $-3.6005^{\star \star \star}$ & $-3.5806^{\star \star \star}$ & $-3.6288^{* * *}$ \\
\hline & $(-16.70)$ & $(-17.46)$ & $(-5.72)$ & $(-6.55)$ & $(-19.37)$ & $(-19.46)$ & $(-11.66)$ & $(-11.92)$ \\
\hline \multirow[t]{2}{*}{ InURB } & $0.2558^{\star \star \star}$ & $0.2525^{\star \star \star}$ & $1.2054^{\star \star \star}$ & $1.2141^{\star \star \star}$ & $0.1264^{\star *}$ & $0.1212^{\star \star}$ & $1.1035^{\star \star \star}$ & $1.1260^{\star \star \star}$ \\
\hline & $(4.02)$ & $(4.03)$ & $(13.63)$ & (17.38) & $(2.14)$ & $(2.14)$ & $(10.80)$ & (12.18) \\
\hline \multirow[t]{2}{*}{ Constant } & $20.1826^{\star \star \star}$ & 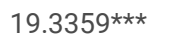 & $17.8823^{\star \star \star}$ & $17.4141^{\star \star \star}$ & $20.8727^{\star \star \star}$ & $20.4688^{\star \star \star}$ & $26.3112^{\star \star \star}$ & $25.9491^{\star \star \star}$ \\
\hline & (15.18) & $(14.96)$ & $(8.46)$ & $(9.03)$ & (24.38) & (23.93) & $(14.40)$ & (13.95) \\
\hline VIF & 5.49 & 5.49 & 8.63 & 8.63 & 2.04 & 2.04 & 2.43 & 2.43 \\
\hline Time Dummies & Yes & Yes & Yes & Yes & Yes & Yes & Yes & Yes \\
\hline No. of Obs. & 271 & 271 & 119 & 119 & 271 & 271 & 136 & 136 \\
\hline R-Squared & 0.815 & 0.825 & 0.939 & 0.946 & 0.764 & 0.768 & 0.882 & 0.881 \\
\hline F Statistic & 45195.883 & 107264.922 & 780.975 & 1046.176 & 1197.225 & 991.080 & 37675.366 & 28788.093 \\
\hline
\end{tabular}

Note: $* \star *, * *$, and $*$ denote statistical significance at the $1 \%, 5 \%$, and $10 \%$ levels, respectively; In = natural logarithm; MINF = infant mortality rates; MU5 = under-5 mortality rate; $\mathrm{CO} 2 \mathrm{PC}=$ carbon emissions per capita; ENUPC = nonrenewable energy per capita; PC = GDP per capita (constant 2010); HEXPC =

health expenditure per capita; SECF = female secondary school enrolment; INFL = inflation rate; BSAN = access to basic sanitation; URB = urban population.

Source: Authors' Computations

\subsection{Results from GMM Dynamic Models}

Controlling for possible endogeneity of the variables, omitted variables and heteroscedasticity, the results from the two-step system GMM are displayed in Table 6. Vividly noticeable, is the statistical significance (at 1 percent level) of the one period lag of the explained variables, infant mortality rate (MINF) and under-5 mortality rate (MU5) respectively which suggests that mortality rate is increasingly persistent in the region. The signs and statistical significance of non-renewable energy align with those from the PSCC-LSDV models while the coefficient of carbon emissions is mostly positive but statistically significant in one out of four models. Overall, this study submits that: (1) mortality rate is persistent; (2) carbon emission show mortality-inducing properties; and (3) nonrenewable energy exert mortality-reducing characteristics.

Table 6 2-Step System GMM Results, Full Sample 


\begin{tabular}{|c|c|c|c|c|}
\hline & \multicolumn{2}{|l|}{ Main Models } & \multirow{2}{*}{$\begin{array}{l}\text { Robustness } \\
\text { [15] }\end{array}$} & \multirow{2}{*}{$\begin{array}{l}\text { Models } \\
{[16]}\end{array}$} \\
\hline & [13] & [14] & & \\
\hline Variables & InMINF & InMU5 & InMINF & InMU5 \\
\hline \multirow[t]{2}{*}{ I.InMINF/I.InMU5 } & $0.933^{\star \star \star}$ & $0.940 * \star \star$ & $0.867 \star \star \star$ & 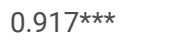 \\
\hline & $(0.016)$ & $(0.014)$ & $(0.011)$ & $(0.016)$ \\
\hline \multirow[t]{2}{*}{ InCO2PC } & 0.016 & 0.029 & $0.057^{*}$ & 0.051 \\
\hline & $(0.018)$ & $(0.030)$ & $(0.030)$ & $(0.038)$ \\
\hline \multirow[t]{2}{*}{ InENUPC } & $-0.056^{\star \star \star}$ & $-0.090 * \star$ & $-0.051^{\star}$ & -0.034 \\
\hline & $(0.017)$ & $(0.037)$ & $(0.027)$ & $(0.044)$ \\
\hline \multirow[t]{2}{*}{$\ln P C$} & $-0.035^{\star \star}$ & -0.022 & & \\
\hline & $(0.015)$ & $(0.016)$ & & \\
\hline \multirow[t]{2}{*}{ InHEXPC } & $0.046 * \star \star$ & $0.038 * \star \star$ & & \\
\hline & $(0.012)$ & $(0.009)$ & & \\
\hline \multirow[t]{2}{*}{ InSECF } & $-0.209 * * *$ & $-0.211 \star \star \star *$ & $-0.292^{\star \star \star}$ & $-0.197 * \star \star$ \\
\hline & $(0.041)$ & $(0.038)$ & $(0.072)$ & $(0.051)$ \\
\hline \multirow[t]{2}{*}{ INFL } & $-0.002^{\star \star \star}$ & -0.001 *** & $-0.003^{\star \star \star}$ & $-0.003^{\star \star \star}$ \\
\hline & $(0.001)$ & $(0.000)$ & $(0.001)$ & $(0.001)$ \\
\hline \multirow[t]{2}{*}{ InBSAN } & -0.203 & 0.182 & $-0.495^{\star \star *}$ & 0.230 \\
\hline & $(0.133)$ & $(0.202)$ & $(0.128)$ & $(0.264)$ \\
\hline \multirow[t]{2}{*}{ InURB } & $0.096^{*}$ & 0.045 & 0.055 & -0.092 \\
\hline & $(0.049)$ & $(0.064)$ & $(0.086)$ & $(0.101)$ \\
\hline \multirow[t]{2}{*}{ Constant } & $1.983^{\star \star *}$ & 0.627 & 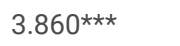 & 0.553 \\
\hline & $(0.568)$ & $(0.794)$ & $(0.573)$ & (1.038) \\
\hline Time Dummies & Yes & Yes & Yes & Yes \\
\hline Observations & 355 & 355 & 371 & 371 \\
\hline $\mathrm{AR}(2) /$ Hansen & $0.734 / 0.132$ & $0.588 / 0.092$ & $0.838 / 0.377$ & $0.369 / 0.109$ \\
\hline Instruments/Groups & $30 / 39$ & $30 / 39$ & $30 / 41$ & $30 / 41$ \\
\hline Wald Statistics & $1.010 \mathrm{e}+06$ & $2.001 \mathrm{e}+06$ & 204896 & 457583 \\
\hline
\end{tabular}

Note: ${ }^{* *}$ and * denote statistical significance at the $1 \%$ and $10 \%$ levels, respectively; In = natural logarithm; MINF = infant mortality rates; MU5 = under-5 mortality rate; $\mathrm{CO} 2 \mathrm{PC}=$ carbon emissions per capita; $\mathrm{ENUPC}=$ nonrenewable energy per capita; $\mathrm{PC}=\mathrm{GDP}$ per capita (constant 2010); HEXPC = health expenditure per capita; $S E C F=$ female secondary school enrolment; INFL = inflation rate; $B S A N=$ access to basic sanitation; URB = urban population. Source: Authors' Computations

\subsection{Results from Simultaneous Quantile Analysis}

For brevity, the interpretations focus only on the impact of carbon emissions and non-renewable energy across different quantiles of infant and under-5 mortality rate. Table 7 and 8 reveals that across the distribution, carbon emission exacerbates both infant and under-5 mortalities though with more significance on the infant mortality rate model. Supporting earlier results from the PSCC-LSDV and system GMM techniques, close scrutiny of the results in Table 7 reveals that the percentage of increase on mortality rate from a percentage increase in carbon emissions ranges between $0.483 \%$ at the 0.05 quantile to $0.424 \%$ at the 0.95 quantile. This finding support earlier literature on the devastating impact of emissions on human health (Ergogan et al., 2019 ; Sarkodie et al., 2019; Owusu \& Sarkodie, 2020). We observe that the impact, though positive and statistically significant at the $1 \%$ level declines at higher distribution of infant mortality rate. The plausible explanation is that modern technology and the adoption of renewable technology by richer countries in Europe dampen the hazardous effects of carbon emissions. Contrarily, the positive impact of emissions on under- 5 mortalities (Table 8 ) is about $0.42 \%$ and significant only at the 0.70 and 0.80 quantiles. Like the pattern observed in Table 7, the positive effect of carbon emissions on under- 5 mortality reduces across the quantiles, though mostly statistically not significant. Also, non-renewable energy shows mortality-reducing problems. The elasticity of impact on infant mortality is statistical significance at the 0.30 to 0.95 quantiles. That is, energy consumption contributes to the reduction of mortality rate by $0.297 \%$ to $0.493 \%$, on average, ceteris paribus. Cursory observation also shows that at higher distribution of infant mortality rate, the mortality-reducing effect of non-renewable energy increases in absolute terms. Again, the most plausible explanation could be the departure from non-renewable energy to adoption of cleaner and environmentally friendly energy sources. Similar to the outcomes of carbon emission on under-5 mortality rate, the negative impact of emissions on under- 5 mortality rate is evident 
only at the 0.70 and 0.80 quantiles with the effect ranging between $-0.404 \%$ and $0.424 \%$. Also, the reducing-effect increases (in absolute terms) across the quantiles, though mostly statistically not significant. Due to the high collinearity between PC and HEXPC, we estimated the quantile models backing out these two variables. The results which are shown in Appendix Table 1B and 1C are not significantly different from Table 7 and 8.

Table 7 Distributional Effects of Carbon Emissions and Non-renewable Energy Consumption on Infant Mortality Rate

\begin{tabular}{|c|c|c|c|c|c|c|c|c|c|c|c|}
\hline & (1) & (2) & (3) & (4) & (5) & (6) & (7) & (8) & (9) & (10) & (11) \\
\hline VARIABLES & 0.05 & 0.1 & 0.2 & 0.3 & 0.4 & 0.5 & 0.6 & 0.7 & 0.8 & 0.9 & 0.95 \\
\hline \multirow[t]{2}{*}{ InCO2PC } & $0.483^{\star * *}$ & $0.478^{\star \star *}$ & $0.471^{\star \star \star}$ & $0.466^{\star \star \star}$ & $0.460 * \star \star$ & $0.453^{\star \star *}$ & $0.447 * \star \star$ & $0.442^{\star \star \star}$ & $0.439 * \star *$ & $0.433^{\star \star \star}$ & $0.424^{\star \star}$ \\
\hline & $(0.168)$ & $(0.144)$ & $(0.117)$ & $(0.099)$ & $(0.084)$ & $(0.077)$ & $(0.085)$ & $(0.097)$ & $(0.110)$ & $(0.135)$ & $(0.171)$ \\
\hline \multirow[t]{2}{*}{ InENUPC } & -0.217 & -0.241 & -0.273 & $-0.297 \star \star$ & $-0.322^{\star \star}$ & 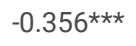 & 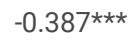 & $-0.408^{* \star \star}$ & $-0.425^{\star \star \star}$ & $-0.455^{\star \star}$ & $-0.493^{\star}$ \\
\hline & $(0.252)$ & $(0.216)$ & $(0.175)$ & $(0.148)$ & $(0.126)$ & $(0.116)$ & $(0.128)$ & $(0.146)$ & $(0.164)$ & $(0.202)$ & $(0.257)$ \\
\hline \multirow[t]{2}{*}{ InPC } & $-0.580 \star \star$ & $-0.521^{\star *}$ & $-0.444^{\star *}$ & $-0.386^{\star \star}$ & $-0.323^{\star *}$ & $-0.242^{*}$ & -0.166 & -0.113 & -0.073 & 0.000 & 0.093 \\
\hline & $(0.289)$ & $(0.247)$ & $(0.200)$ & $(0.170)$ & $(0.145)$ & $(0.134)$ & $(0.147)$ & $(0.167)$ & $(0.188)$ & $(0.232)$ & $(0.296)$ \\
\hline \multirow[t]{2}{*}{ InHEXPC } & $-0.166^{\star}$ & $-0.188^{\star *}$ & $-0.217 * \star \star$ & 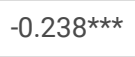 & $-0.261^{\star \star \star}$ & 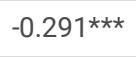 & $-0.319 * \star \star$ & $-0.338^{\star \star \star}$ & $-0.353^{\star \star \star}$ & $-0.380 * \star \star *$ & $-0.414^{\star \star \star}$ \\
\hline & $(0.095)$ & $(0.081)$ & $(0.066)$ & $(0.056)$ & $(0.048)$ & $(0.044)$ & $(0.048)$ & $(0.055)$ & $(0.061)$ & $(0.076)$ & $(0.097)$ \\
\hline \multirow[t]{2}{*}{ InSECF } & -0.355 & -0.307 & -0.244 & -0.197 & -0.146 & -0.080 & -0.018 & 0.025 & 0.058 & 0.117 & 0.193 \\
\hline & $(0.231)$ & $(0.197)$ & $(0.160)$ & $(0.135)$ & $(0.116)$ & $(0.107)$ & $(0.117)$ & $(0.133)$ & $(0.150)$ & $(0.185)$ & $(0.236)$ \\
\hline \multirow[t]{2}{*}{ INFL } & 0.002 & 0.003 & 0.003 & 0.003 & $0.004^{*}$ & $0.004^{* *}$ & $0.005^{\star \star}$ & $0.005^{\star}$ & $0.005^{\star}$ & 0.005 & 0.006 \\
\hline & $(0.004)$ & $(0.004)$ & $(0.003)$ & $(0.003)$ & $(0.002)$ & $(0.002)$ & $(0.002)$ & $(0.003)$ & $(0.003)$ & $(0.004)$ & $(0.004)$ \\
\hline \multirow[t]{2}{*}{ InBSAN } & -1.353 & -1.420 & $-1.507^{\star}$ & $-1.573^{* *}$ & $-1.644^{\star \star \star}$ & $-1.736^{\star \star \star}$ & $-1.822^{\star \star *}$ & $-1.882^{\star \star \star}$ & $-1.928 * \star$ & $-2.010 * \star$ & $-2.116^{\star}$ \\
\hline & $(1.249)$ & $(1.076)$ & $(0.869)$ & $(0.735)$ & $(0.625)$ & $(0.572)$ & $(0.633)$ & $(0.726)$ & $(0.816)$ & $(1.005)$ & $(1.274)$ \\
\hline \multirow[t]{2}{*}{ InURB } & $-2.419 \star \star$ & $-2.495^{\star \star \star}$ & $-2.592^{\star \star \star}$ & $-2.665^{\star \star \star}$ & $-2.745^{\star \star \star}$ & $-2.848^{\star \star \star}$ & $-2.944^{\star \star \star}$ & $-3.011^{\star * *}$ & $-3.063^{\star \star \star}$ & $-3.155^{\star \star *}$ & $-3.273^{\star \star \star}$ \\
\hline & $(1.019)$ & $(0.877)$ & $(0.709)$ & $(0.600)$ & $(0.510)$ & $(0.467)$ & $(0.516)$ & $(0.592)$ & $(0.666)$ & $(0.820)$ & (1.039) \\
\hline Observations & 390 & 390 & 390 & 390 & 390 & 390 & 390 & 390 & 390 & 390 & 390 \\
\hline
\end{tabular}

Table 8 Distributional Effects of Carbon Emissions and Non-renewable Energy Consumption on Under-5 Mortality Rate 


\begin{tabular}{|c|c|c|c|c|c|c|c|c|c|c|c|}
\hline & (1) & (2) & (3) & (4) & (5) & (6) & (7) & (8) & (9) & (10) & (11) \\
\hline VARIABLES & 0.05 & 0.1 & 0.2 & 0.3 & 0.4 & 0.5 & 0.6 & 0.7 & 0.8 & 0.9 & 0.95 \\
\hline \multirow[t]{2}{*}{ InCO2PC } & 0.454 & 0.450 & 0.447 & 0.442 & 0.438 & 0.433 & 0.427 & $0.424^{\star \star \star}$ & $0.421^{* * \star}$ & 0.415 & 0.411 \\
\hline & $(1.725)$ & (1.554) & (1.333) & (1.077) & $(0.871)$ & $(0.592)$ & $(0.293)$ & $(0.146)$ & $(0.139)$ & $(0.439)$ & $(0.657)$ \\
\hline \multirow[t]{2}{*}{ InENUPC } & -0.201 & -0.222 & -0.250 & -0.282 & -0.307 & -0.343 & -0.381 & $-0.404^{*}$ & $-0.424^{\star \star}$ & -0.467 & -0.495 \\
\hline & (2.595) & $(2.337)$ & $(2.005)$ & $(1.620)$ & $(1.310)$ & $(0.891)$ & $(0.441)$ & $(0.220)$ & $(0.209)$ & $(0.660)$ & $(0.988)$ \\
\hline \multirow[t]{2}{*}{$\operatorname{lnPC}$} & -0.577 & -0.532 & -0.474 & -0.407 & -0.353 & -0.279 & -0.198 & -0.151 & -0.109 & -0.018 & 0.040 \\
\hline & $(2.946)$ & (2.654) & $(2.277)$ & $(1.839)$ & (1.488) & $(1.011)$ & $(0.501)$ & $(0.250)$ & $(0.238)$ & $(0.750)$ & (1.123) \\
\hline \multirow[t]{2}{*}{ InHEXPC } & -0.175 & -0.191 & -0.211 & -0.235 & -0.254 & -0.280 & $-0.309 *$ & $-0.326^{\star \star \star}$ & $-0.341^{\star \star \star}$ & -0.373 & -0.394 \\
\hline & $(0.963)$ & $(0.868)$ & $(0.744)$ & $(0.601)$ & $(0.486)$ & $(0.331)$ & $(0.164)$ & $(0.082)$ & $(0.078)$ & $(0.245)$ & $(0.367)$ \\
\hline \multirow[t]{2}{*}{ InSECF } & -0.313 & -0.280 & -0.238 & -0.188 & -0.149 & -0.095 & -0.035 & -0.000 & 0.031 & 0.097 & 0.140 \\
\hline & $(2.353)$ & $(2.120)$ & (1.819) & $(1.469)$ & (1.188) & $(0.808)$ & $(0.400)$ & $(0.200)$ & $(0.190)$ & $(0.599)$ & $(0.897)$ \\
\hline \multirow[t]{2}{*}{ INFL } & 0.002 & 0.003 & 0.003 & 0.003 & 0.004 & 0.004 & 0.005 & 0.005 & 0.005 & 0.006 & 0.006 \\
\hline & $(0.045)$ & $(0.041)$ & $(0.035)$ & $(0.028)$ & $(0.023)$ & $(0.016)$ & $(0.008)$ & $(0.004)$ & $(0.004)$ & $(0.012)$ & $(0.017)$ \\
\hline \multirow[t]{2}{*}{ InBSAN } & -1.363 & -1.413 & -1.478 & -1.554 & -1.614 & -1.697 & -1.789 & $-1.842^{*}$ & $-1.889 *$ & -1.991 & -2.057 \\
\hline & (12.888) & (11.608) & $(9.960)$ & $(8.043)$ & (6.508) & $(4.423)$ & $(2.191)$ & $(1.094)$ & (1.038) & (3.277) & (4.908) \\
\hline \multirow[t]{2}{*}{ InURB } & -2.640 & -2.692 & -2.759 & -2.837 & -2.899 & -2.985 & $-3.079 *$ & $-3.134^{\star \star \star}$ & $-3.182^{\star \star \star}$ & -3.288 & -3.355 \\
\hline & (10.005) & (9.011) & (7.731) & $(6.244)$ & $(5.052)$ & (3.433) & (1.701) & $(0.849)$ & $(0.806)$ & (2.544) & (3.810) \\
\hline Observations & 390 & 390 & 390 & 390 & 390 & 390 & 390 & 390 & 390 & 390 & 390 \\
\hline
\end{tabular}

Note: $* \star * p<0.01, * \star p<0.05,{ }^{*} p<0.1$ Standard errors in (

)

\section{Conclusion And Policy Recommendations}

This study aligns with the 2030 United Nations Sustainable Development Goals 3 and 11 which aim to promote healthy lives as well as wellbeing and make cities and human settlements sustainable, resilient and safe, respectively. It exclusively contributes to the health-environment discourse by using mortality rates, carbon emissions and non-renewable energy to investigate these intrinsic relationships for an unbalanced sample of 46 European countries from 2005 to 2015. For the full sample, consistent findings from the PSCC-LSDV, system GMM and quantile regressions reveal that carbon emissions exacerbate infant and under-5 mortality rates while non-renewable energy exhibit mortality-reducing properties. Noticeably, the mortality-increasing impact of emissions reduces while that from non-renewable energy increases at higher distribution of mortality rates. For the sub-samples, we find that emissions significantly (robustness model) reduce mortality rate in the Euro Union countries relative to non-Euro countries. In addition, non-renewable energy exhibit mortality-reducing properties in both sub-samples but with higher elasticity in non-Euro countries. Lastly, the results from the GMM estimations affirm the persistency of infant and under- 5 mortality rates in the data.

Some policy recommendations. Although we have found that non-renewable energy consumption reduces the mortality rate, it should be noted that renewables have the capacity to curb the effects of carbon emissions and, therefore, increase both health and environmental quality. Besides, excessive extraction of non-renewable resources can make a country vulnerable towards shocks. Hence, it is important to promote green solutions to attain friendly and sustainable environment in European countries. Green solutions involve replacing fossil fuel or non-renewable resources with renewable energy technologies and obtaining energy efficiency. Both these two tools (being energy efficient and developing renewables) can improve the climate and human health by replacing the harmful emission gases and air pollutants such as PM2.5 (Buonocore et al., 2016). The renewables are not only effective alternatives to fossil fuels, but they also contain numerous positive externalities. By reducing the human beings' exposure to respiratory and cardiovascular diseases that arises from fossil fuel burning, renewables offer significant positive benefit to the health sector. Since our objective was to look at the effect of carbon emissions on health, we did not include regulatory control in our model. For further studies, the role of regulatory control on the health-environment dynamics may be taken up.

\section{Declarations}

Acknowledgments: None

Data availability: Data will be made available upon request.

Details of funding sources that supported the work: No funding received. 
Conflict of interest/Competing interest: Authors declare no competing interests.

Authors' contributions: BNA conceptualised and designed the study and analyzed and interpreted the data. AKT supervised and improved the paper and did data analysis. MIS interpretation of results and writing reviewing and editing. SU interpretation of results and writing reviewing and editing. All authors read and approved the final manuscript.

\section{References}

Adedotun, A.F., Obadina O.G., Adesina O.S., Omosanya K.O., \& Dare, R.J. (2018). Statistical analysis of the effect of environmental degradation on mortality rate: a vector autoregressive (VAR) model approach. International Journal of Science and Engineering Invention, 04(11), 5-14

Adeleye, B. N., Adedoyin, F. F., \& Nathaniel, S. (2020). The Criticality of ICT-Trade Nexus on Economic and Inclusive growth. Information Technology for Development. doi:10.1080/02681102.2020.1840323

Adeleye, B. N., Gershon, O., Ogundipe, A., Owolabi, O., Ogunrinola, I., \& Adediran, O. (2020). Comparative investigation of the growth-poverty-inequality trilemma in Sub-Saharan Africa and Latin American and Caribbean Countries. Heliyon, 6(e05631), 1-11. doi:https://doi.org/10.1016/j.heliyon.2020.e05631

Ahmad, A., Zhao, Y., Shahbaz, M., Bano, S., Zhang, Z., Wang, S., \& Liu, Y. (2016). Carbon emissions, energy consumption and economic growth: an aggregate and disaggregate analysis of the Indian economy. Energy Policy, 96, 131-143.

Ahmad, M., Ur Rahman, Z., Hong, L., Khan, S., Khan, Z., \& Naeem Khan, M. (2018). Impact of environmental quality variables and socio-economic factors on human health: empirical evidence from China. Pollution, 4(4), 571-579.

Ali, A., \& Audi, M. (2016). The impact of income inequality, environmental degradation and globalization on life expectancy in Pakistan: an empirical analysis.

Alimi, O. Y., Ajide, K. B., \& Isola, W. A. (2019). Environmental quality and health expenditure in ECOWAS. Environment, Development and Sustainability, 1-23.

Amann M, Bertok I, Cofala J, et al. Baseline scenarios for the Clean Air for Europe (CAFE) programme. Final report. Laxenburg, International Institute for Applied Systems Analysis, 2005.

Anderson HR, Spix C, Medina S, et al. Air pollution and daily admissions for chronic obstructive pulmonary disease in 6 European cities: results from the APHEA project. Eur Respir J 1997; 10: 1064-1071.

Anderson H, Atkinson R, Peacock J, et al. Meta-analysis of time-series studies and panel studies of particulate matter (PM) and ozone (O3). Report of a WHO task group. Copenhagen, WHO Regional Office for Europe, 2004.

Anderson, T. W., \& Hsiao. C., (1982)., Formulation and estimation of dynamic models using panel data, Journal of Econometrics, 18: pp. 47-82.

Anser, MK., Hanif, I., Vo, X. V., \& Alharthi, M., (2020). The long-run and short-run influence of environmental pollution, energy consumption, and economic activities on health quality in emerging countries. Environmental Science and Pollution Research, 27:32518-32532

Arellano, M., \& Bond, S. (1991)., Some tests of specification for panel data: Monte Carlo evidence and an application to employment equations. Review of Economic Studies, 58, pp. 277-297.

Arellano, M., \& O., Bover. (1995)., Another look at the instrumental variable estimation of error components models, Journal of Econometrics 68, pp. $29-51$.

Arellano, M., \& S. Bond. (1998)., Dynamic panel data estimation using DPD98 for Gauss: A guide for users. Mimeo. Available at

ftp://ftp.cemfi.es/pdf/papers/ma/dpd98.pdf.

Ari, I., \& Şentürk, H. (2020). The relationship between GDP and methane emissions from solid waste: A panel data analysis for the G7. Sustainable Production and Consumption, 23, 282-290. doi:10.1016/j.spc.2020.06.004

Asghar, M. M., Wang, Z., Wang, B., \& Zaidi, S. A. H., (2020). Nonrenewable energy-environmental and health effects on human capital: empirical evidence from Pakistan. Environmental Science and Pollution Research, 27:2630-2646

Azam, M. \& Ahmed, M. A., (2015). Role of human capital and foreign direct investment in promoting economic growth: Evidence from Commonwealth of Independent States. International Journal of Social Economics, 42(2), 89-111

Badulescu, D., Simut, R., Badulescu, A., \& Badulescu, A. V. (2019). The relative effects of economic growth, environmental pollution and non-communicable diseases on health expenditures in European Union countries. International journal of environmental research and public health, 16(24), 5115.

Barreira, A., Patierno, M., \& Bautista, C. R. (2017). Impacts of Pollution on our Health and the Planet: The Case of Coal Power Plants. In U. Nations (Ed.), UN Environment (pp. 1-10). United Nations: United Nations.

Bell ML, Dominici F, Samet JM. A meta-analysis of time-series studies of ozone and mortality with comparison to the national morbidity, mortality, and air pollution study. Epidemiology 2005; 16: 436-445. 
Brida, J. G., Cortes-Jimenez, I., \& Pulina, M. (2016). Has the tourism-led growth hypothesis been validated? A literature review. Current Issues in Tourism 19: $394-430,19(5), 394-430$.

Buonocore, J. J., Luckow, P., Norris, G., Spengler, J. D., Biewald, B., Fisher, J., \& Levy, J. I. (2016). Health and climate benefits of different energy-efficiency and renewable energy choices. Nature Climate Change, 6(1), 100-105.

Burnett RT, Brook JR, Yung WT, et al. Association between ozone and hospitalization for respiratory diseases in 16 Canadian cities. Environ Res 1997; 72 : 2431.

Cameron, A. \& Trivedi, P. (2005). Microeconometrics, Cambridge University Press

Caruso, G., Colantonio, E., \& Gattone, S. A. (2020). Relationships between Renewable Energy Consumption, Social Factors, and Health: A Panel Vector Auto Regression Analysis of a Cluster of 12 EU Countries. Sustainability MDPT, 12(2915), 1-16. doi:10.3390/su12072915

Chaabouni, S., Zghidi, N., \& Mbarek, M. B. (2016). On the causal dynamics between CO2 emissions, health expenditures and economic growth. Sustainable cities and society, 22, 184-191.

Churchill, S.A., Inekwe, J., Ivanovski, K., Smyth, R., 2018. The environmental Kuznets curve in the OECD: 1870-2014. Energy Econ 75, 389-399. doi: 10.1016/j.eneco. 2018.09.004 .

Edenhofer, O. (Ed.). (2015). Climate change 2014: mitigation of climate change(Vol. 3). Cambridge University Press.

Erdoğan, S., Yıldırım, D. C., \& Gedikli, A., (2019). The relationship between $\mathrm{CO} 2$ emissions and health indicators. Econometrics Letters, 6 (1), $28-39$

Farooq, M. U., Shahzad, U., Sarwar, S., \& ZaiJun, L. (2019). The impact of carbon emission and forest activities on health outcomes: empirical evidence from China. Environmental Science and Pollution Research, 26(13), 12894-12906.

Fotourehchi, Z. (2016). Health effects of air pollution: An empirical analysis for developing Countries. Atmospheric Pollution Research,7, 201- 206. Hansen, L. P. (1982). Large sample properties of generalized method of moment's estimators, Econometrica, 50, pp. 1029-1054.

GEA (2012). Global energy assessment - toward a sustainable future. Cambridge University Press, Cambridge, UK, and New York, NY, USA and the International Institute for Applied Systems Analysis, Laxenburg, Austria.

Geels, C., Andersson, C., Hanninen, O., Lanso, A. S., Schwarze, P. E., Skjoth, C. A., et al. (2015). Future premature mortality due to 03, secondary inorganic aerosols and primary PM in Europe--sensitivity to changes in climate, anthropogenic emissions, population and building stock. Int $J$ Environ Res Public Health, 12(3), 2837-2869. doi:10.3390/ijerph120302837

Gryparis A, Forsberg B, Katsouyanni K, et al. Acute effects of ozone on mortality from the "air pollution and health: a European approach" project. Am J Respir Crit Care Med 2004; 170: 1080-1087.

Hoechle, D. (2006). Robust Standard Errors for Panel Regressions with Cross-Sectional Dependence. The Stata Journal, 1-31

Hossain, S., Siddika, M. A., Koly, I. J., \& Akter, K. (2020). Exploring the Impact of Environmental Degradation on Life Expectancy in Bangladesh: An ARDL Bounds Test Approach. International Journal of Science and Business, 4(12), 69-79.

Huq, S.M., Ashraf, B.N., Gupta, A.D. \& Zheng, C., (2018)., Does bank diversification heterogeneously affect performance and risk-taking in ASEAN emerging economies? Res. Int. Bus. Finance

Jian, Y., Messer, L. C., Jagai, J. S., Rappazzo, K. M., Gray, C. L., Grabich, S. C., \& Lobdell, D. T. (2017). Associations between environmental quality and mortality in the contiguous United States, 2000-2005. Environmental health perspectives, 125(3), 355-362.

Katrakilidis, C., Kyritsis, I., \& Patsika, V. (2016). The dynamic linkages between economic growth, environmental quality and health in Greece. Applied Economics Letters, 23(3), 217-221.

Kim J., (2017)., bank competition and financial stability: liquidity risk Perspective, Contemporary Economic Policy, Vol. 36, No. 2, 337-362,

Koenker, R. (2005). Quantile Regression. New York: Cambridge University Press.

Koenker, R., \& Bassett, G. (1978). Regression Quantiles. Econometrica, 46(33-50).

Koenker, R., \& Hallock, K. F. (2001). Quantile Regression. Journal of Econometrics Perspectives, 15, 143-156.

Ito K, De Leon SF, Lippmann M. Associations between ozone and daily mortality: analysis and meta-analysis. Epidemiology 2005; 16:446-457.

Kolasa-Więcek, A., \& Suszanowicz, D. (2019). Air pollution in European countries and life expectancy-modelling with the use of neural network. Air Quality, Atmosphere \& Health, 12(11), 1335-1345. 
Kushta, J., Paisi, N., Van Der Gon, H. D., \& Lelieveld, J. (2021). Disease burden and excess mortality from coal-fired power plant emissions in Europe. Environmental Research Letters, 16(4), 045010. doi:10.1088/1748-9326/abecff

Levy JI, Chemerynski SM, Sarnat JA. Ozone exposure and mortality: an empiric bayes meta-regression analysis. Epidemiology 2005; 16: 458-468.

Li, F., 2016, Endogeneity in CEO power: A survey and experiment, Investment Analysts Journal 45 (3): 149-162., Available at SSRN:

https://ssrn.com/abstract=1785204 or http://dx.doi.org/10.2139/ssrn.1785204

Mehrara, M., \& Nasibparast, S. (2013). A Bayesian Econometric Approach to Specify the Determinants of Health Status in Developing Countries. Quarterly Journal of Applied Theories of Economics, 1(2), 1-28.

Mujtaba, G., \& Shahzad, S. J. H. (2021). Air pollutants, economic growth and public health: implications for sustainable development in OECD countries. Environmental Science and Pollution Research, 28(10), 12686-12698.

McKee, M., \& Jacobson, B. (2000). Public health in Europe. The Lancet, 356(9230), 665-670.

Meehl, G. A., \& Tebaldi, C. (2004). More intense, more frequent, and longer lasting heat waves in the 21st century. Science, 305(5686), 994-997.

Mortimer KM, Neas LM, Dockery DW, et al. The effect of air pollution on inner-city children with asthma. Eur Respir J 2002; 19:699-705.

Mutizwa, A., \& Makochekanwa, A., (2015). Impact of environmental quality on health status: a study of 12 Southern African Development Community (SADC) Countries between 2000 and 2008. BOJE: Botswana Journal of Economics, 13(1), 87-111

Nathaniel, S. P., \& Adeleye, N. (2021). Environmental preservation amidst carbon emissions, energy consumption, and urbanization in selected African countries: Implication for sustainability. Journal of Cleaner Production, 285, 125409.

Nkengfack, H., Fotio, H. K., \& Totouom, A. (2020). How Does the Shadow Economy Affect Environmental Quality in Sub-Saharan Africa? Evidence from Heterogeneous Panel Estimations. Journal of the Knowledge Economy. doi:https://doi.org/10.1007/s13132-020-00685-7

Noman AHM, Gee CS, Isa CR (2017)., Does competition improve financial stability of the banking sector in ASEAN countries? An empirical analysis, PLoS ONE 12(5): e0176546. https://doi.org/10.1371/journal.pone.0176546

Okafor, A., Adeleye, B. N., \& Adusei, M. (2021). Corporate Social Responsibility and Financial Performance: Evidence from U.S Tech Firm. Journal of Cleaner Production, 292(126078), 1-11.

Orru, H., Andersson, C., Ebi, K. L., Langner, J., Astrom, C., \& Forsberg, B. (2013). Impact of climate change on ozone-related mortality and morbidity in Europe. Eur Respir J, 41(2), 285-294. doi:10.1183/09031936.00210411

Orru, H., Åström, C., Andersson, C., Tamm, T., Ebi, K. L., \& Forsberg, B. (2019). Ozone and heat-related mortality in Europe in 2050 significantly affected by changes in climate, population and greenhouse gas emission. Environmental Research Letters, 14(7), 074013. doi:10.1088/1748-9326/ab1cd9

Owusu, P. A., \& Sarkodie, S. A. (2020). Global estimation of mortality, disability-adjusted life years and welfare cost from exposure to ambient air pollution. Science of the Total Environment, 742, 140636.

Pablo-Romero, M. D. P., Román, R., Sánchez-Braza, A., \& Yñiguez, R. (2016). Renewable energy, emissions, and health. Renewable Energy: Utilisation and System Integration, 173.

Patel, A. P., Jagai, J. S., Messer, L. C., Gray, C. L., Rappazzo, K. M., Deflorio-Barker, S. A., \& Lobdell, D. T. (2018). Associations between environmental quality and infant mortality in the United States, 2000-2005. Archives of Public Health, 76(1), 1-11.

Peters JM, Avol E, Gauderman WJ, et al. A study of twelve Southern California communities with differing levels and types of air pollution. II. Effects on pulmonary function. Am J Respir Crit Care Med 1999; 159: 768-775.

Robine, J. M., Cheung, S. L. K., Le Roy, S., Van Oyen, H., Griffiths, C., Michel, J. P., \& Herrmann, F. R. (2008). Death toll exceeded 70,000 in Europe during the summer of 2003. Comptes rendus biologies, 331(2), 171-178.

Roodman, D. (2014). "xtabond2: Stata Module to Extend xtabond Dynamic Panel Data Estimator", Statistical Software Components.

Sarkodie, S. A., Strezov, V., Jiang, Y., \& Evans, T. (2019). Proximate determinants of particulate matter (PM2.5) emission, mortality and life expectancy in Europe, Central Asia, Australia, Canada and the US. Sci Total Environ, 683, 489-497. doi:10.1016/j.scitotenv.2019.05.278

Sarofim, M. C., Waldhoff, S. T., \& Anenberg, S. C. (2017). Valuing the Ozone-Related Health Benefits of Methane Emission Controls. Environmental Resource Economics, 66, 45-63. doi:10.1007/s10640-015-9937-6

Shahbaz, M., Haouas, I. and Van Hoang, T.H. (2019), “Economic growth and environmental degradation in vietnam is the environmental kuznets curve a complete picture?”, Emerging Markets Review, Vol. 38, pp. 197-218. 
Shahzad, K., Jianqiu, Z., Hashim, M., Nazam, M., \& Wang, L. (2020). Impact of using information and communication technology and renewable energy on health expenditure: A case study from Pakistan. Energy, 204, 117956.

Shobande, O.A (2020). The effects of energy use on infant mortality rates in Africa. Environmental and Sustainability Indicators, 5(2020) 100015.

Ullah, I., Rehman, A., Khan, F. U., Shah, M. H., \& Khan, F. (2020). Nexus between trade, CO2 emissions, renewable energy, and health expenditure in Pakistan. The International journal of health planning and management, 35(4), 818-831.

United States Environmental Protection Agency (US EPA). (2017). Global Greenhouse gas emission data. Accessed on 11th June 2018, from https://www.epa.gov/ghgemissions/globalgreenhouse-gas-emissions-data

Yu, Y., Zhang, L., \& Zheng, X. (2016). On the nexus of environmental quality and public spending on health care in China: a panel cointegration analysis. Economic and Political Studies, 4(3), 319-331.

Zeeshan, M., Han, J., Rehman, A., Ullah, I., \& Afridi, F. E. A. (2021). Exploring Asymmetric Nexus Between CO 2 Emissions, Environmental Pollution, and Household Health Expenditure in China. Risk Management and Healthcare Policy, 14, 527-539.

Wang, C. M., Hsueh, H. P., Li, F., \& Wu, C. F. (2019). Bootstrap ARDL on health expenditure, CO2 emissions, and GDP growth relationship for 18 OECD countries. Frontiers in public health, 7, 324 .

World Health Organization(WHO). (2018). Climate change and health. https://www.who.int/news-room/fact-sheets/detail/climate-change-and-health World Health Organization. (2002). Health and sustainable development: Key health trends (No. WHO/HDE/HID/02.2). World Health Organization.

\section{Supplementary Files}

This is a list of supplementary files associated with this preprint. Click to download.

- Appendix.docx 